\title{
16S rRNA and amoA-based phylogeny of 12 novel betaproteobacterial ammonia-oxidizing isolates: extension of the dataset and proposal of a new lineage within the nitrosomonads
}

Correspondence Michael Wagner wagner@microbial-ecology.net

\section{INTRODUCTION}

Chemolithoautotrophic ammonia-oxidizing bacteria (AOB) are capable of gaining energy via conversion of ammonia to nitrite and are thus of considerable importance in the global nitrogen cycle. Almost all aerobic environments in which organic matter is mineralized are possible habitats for $\mathrm{AOB}$ (Bock \& Wagner, 2001). They have been detected in a variety of soil, marine, estuarine and freshwater systems and are crucial for the removal of nitrogen compounds in wastewater treatment plants (Painter, 1986), thus contributing to

\section{Abbreviation: $\mathrm{AOB}$, ammonia-oxidizing bacteria.}

The GenBank accession numbers for the sequences determined in this study are AY123787-AY123813 (16S rRNA gene sequences) and AY123815-AY123840 (amoA and AmoA sequences).

Supplementary data are available for $16 \mathrm{~S}$ rRNA gene sequences and amoA/AmoA sequences. the impairment of anthropogenic damage to the environment. On the other hand, AOB activity causes deterioration of natural building stones (Bock \& Sand, 1993) and enhances nitrogen fertilizer loss from arable soil (MacDonald, 1986). Due to their importance in natural and engineered systems, significant efforts have been made to characterize the diversity, distribution patterns and ecophysiology of $\mathrm{AOB}$ (for reviews see Koops \& Pommerening-Röser, 2001; Kowalchuk \& Stephen, 2001; Koops et al., 2003).

The first isolation of AOB was reported in 1890 (Frankland \& Frankland, 1890; Winogradsky, 1890) and since then a considerable number of $\mathrm{AOB}$ isolates was obtained from various environments, leading to the description of $16 \mathrm{AOB}$ species (reviewed by Koops et al., 2003). Comparative $16 \mathrm{~S}$ rRNA gene sequence analyses of these species showed that 'Nitrosococcus halophilus' and Nitrosococcus oceani belong to the class 'Gammaproteobacteria', while the remaining 14 
species form a monophyletic lineage within the class 'Betaproteobacteria' (Head et al., 1993; PommereningRöser et al., 1996; Purkhold et al., 2000; Stehr et al., 1995a; Teske et al., 1994; Woese et al., 1984, 1985). Betaproteobacterial AOB encompass the genera Nitrosomonas (including 'Nitrosococcus mobilis') and Nitrosospira (including Nitrosolobus and 'Nitrosovibrio'; Head et al., 1993). Cultured nitrosomonads can be subdivided further into five phylogenetically well-defined lineages (PommereningRöser et al., 1996; Purkhold et al., 2000; Stephen et al., 1996). A similar subdivision system has been suggested also for nitrosospiras and was used to assign cultured nitrosospiras into four 'clusters' (Pommerening-Röser et al., 1996; Purkhold et al., 2000; Stephen et al., 1996). However, due to the close phylogenetic relationship of all known nitrosospiras with each other, their subdivision is not well supported by phylogeny inference methods (Purkhold et al., 2000; Koops et al., 2003). The current perception of AOB phylogeny established by comparative $16 \mathrm{~S}$ rRNA sequence analysis could be confirmed independently by exploiting the gene amoA, which encodes the active site subunit of the enzyme ammonia monooxygenase (AmoA), as an alternative phylogenetic marker (Klotz \& Norton, 1995; McTavish et al., 1993; Purkhold et al., 2000; Rotthauwe et al., 1995). Generally, $16 \mathrm{~S}$ rRNA and amoA-based trees possess congruent topologies, although the fragment of the latter gene, which is usually used for phylogeny inference, provides less resolution (Koops et al., 2003).

Cultivation-dependent analysis of environmental AOB diversity is time consuming and tedious due to the slow growth rates of these microorganisms. Furthermore, the enrichment and isolation strategies currently applied might fail to recover the entire diversity of this guild. Triggered by these limitations, the last decade saw an enormous increase in molecular, cultivation-independent diversity surveys of AOB. 16S rRNA gene sequences retrieved directly from environmental samples revealed that, with the exception of two lineages within the nitrosomonads (Stephen et al., 1996; de Bie et al., 2001) and one cluster within the nitrosospiras (Stephen et al., 1996), most sequences retrieved environmentally are closely related to cultured AOB (reviewed by Purkhold et al., 2000). Similar findings were obtained by phylogenetic analysis of environmental amoA gene fragments (Casciotti \& Ward, 2001; Hommes et al., 1998; Klotz \& Norton, 1995; McTavish et al., 1993; Purkhold et al., 2000; Rotthauwe et al., 1997; Yamagata et al., 1999).

In the present study, we extended the current $16 \mathrm{~S}$ rRNA and amo $A$ gene databases of $\mathrm{AOB}$ by (i) determining the respective sequences of 12 novel $\mathrm{AOB}$ isolates and (ii) improving the length and/or quality of several sequences of other $\mathrm{AOB}$ published previously. Based on these data, a thorough phylogenetic analysis of betaproteobacterial AOB was performed to obtain a phylogenetic framework, which is required for the design and specificity evaluation of PCR primers and probes and which allows the assignment of environmentally retrieved sequences. Based on the findings obtained, we propose a new lineage within the nitrosomonads which also encompasses many $16 \mathrm{~S}$ rRNA gene clones from marine systems that were not assigned previously.

\section{METHODS}

Pure cultures of AOB. Table 1 summarizes the strains investigated in this study. AOB were cultured using the media and conditions described previously (Koops et al., 1991).

DNA-DNA hybridization. DNA similarities were estimated by photometric determination of thermal renaturation rates, as described by Koops \& Harms (1985).

DNA extraction for PCR. AOB were harvested from 101 of exponentially growing cultures by continuous flow centrifugation $(20000 \mathrm{~g}$, $400 \mathrm{ml} \mathrm{min}^{-1}$ ). Total genomic DNA was extracted according to the following protocol: a $0.25 \mathrm{~g}$ pellet (wet wt) of each sample was resuspended in a $2 \mathrm{ml}$ polypropylene tube containing glass beads (Fast DNA Spin kit for soil; BIO 101) with $500 \mu \mathrm{l}$ AE buffer (20 mM sodium acetate, $1 \mathrm{mM}$ EDTA, pH $5 \cdot 5$, adjusted with acetic acid), $50 \mu \mathrm{l} 25 \%$ SDS and $600 \mu \mathrm{l}$ phenol/chloroform/isoamyl alcohol (25:24:1, by vol.). Cells were lysed in a BeadBeater (BIO $101 ; 2 \times 15 \mathrm{~s}$, speed setting $4 \cdot 5)$ and the mixture was then centrifuged $\left(10 \mathrm{~min}, 10000 \mathrm{~g}, 4^{\circ} \mathrm{C}\right)$. The aqueous phase was transferred carefully to a fresh tube, mixed with $600 \mu \mathrm{l}$ chloroform/isoamyl alcohol $(24: 1, \mathrm{v} / \mathrm{v})$ and centrifuged $(10 \mathrm{~min}, 10000 \mathrm{~g})$. The aqueous phase was transferred to a fresh tube and, after the addition of $0 \cdot 1$ vol. $3 \mathrm{M}$ sodium acetate, nucleic acids were precipitated by incubation with 0.6 vol. 2-propanol and $5 \mu$ l glycogen $\left(5 \mathrm{mg} \mathrm{ml}^{-1}\right)$ for $1 \mathrm{~h}$ at $-20^{\circ} \mathrm{C}$ and subsequently pelleted by centrifugation $(20 \mathrm{~min}$, $10000 \mathrm{~g}, 4^{\circ} \mathrm{C}$ ). Pellets were washed with $1 \mathrm{ml}$ ice-cold $70 \%$ ethanol, dried and resuspended in $30-50 \mu$ l elution buffer $(10 \mathrm{mM}$ Tris $/ \mathrm{HCl}$, $\mathrm{pH} 8 \cdot 5)$.

PCR amplification of 16S rDNA. Amplification of 16S rRNA genes was performed as specified by Juretschko et al. (1998) and Purkhold et al. (2000) using the primers 616F and 630R.

PCR amplification of the amoA gene fragment. A $453 \mathrm{bp}$ fragment (without primers) of the amoA gene was amplified from 100 ng DNA using the optimized (Stephen et al., 1999) primers amoA-1F and amoA-2R (Rotthauwe et al., 1997) for PCR with a Primus cycler (MWG Biotech). Reaction mixtures containing $50 \mathrm{pM}$ of each primer were prepared in a total volume of $50 \mu \mathrm{l}$ using $20 \mathrm{mM} \mathrm{MgCl} 2$ reaction buffer and $1.5 \mathrm{U}$ Taq polymerase (Promega). Thermal cycling was carried out by an initial denaturation step at $94{ }^{\circ} \mathrm{C}$ for $1 \mathrm{~min}$, followed by 30 cycles of denaturation at $94{ }^{\circ} \mathrm{C}$ for $20 \mathrm{~s}$, annealing at $50^{\circ} \mathrm{C}$ for $20 \mathrm{~s}$ and elongation at $72{ }^{\circ} \mathrm{C}$ for $40 \mathrm{~s}$. Cycling was completed by a final elongation step at $72{ }^{\circ} \mathrm{C}$ for $5 \mathrm{~min}$.

Cloning, sequencing and phylogeny inference. The amplified $16 \mathrm{~S}$ rRNA and $a m o A$ gene fragments were cloned according to the manufacturer's instructions into pCR2.1 TOPO TA vectors (Invitrogen). After plasmid purification (Qiagen), sequences were determined using a Thermo Sequenase Cycle sequencing kit (Amersham), infrared-labelled (IRD 800) primers and an automated DNA sequencer (Li-Cor). 16S rRNA and amoA gene sequences were added to the respective database using the ARB program package (http://www.arb-home.de). Sequences were aligned using the package's implemented tools and corrected by visual inspection. Phylogenetic analyses were performed based on nucleic acid (16S rRNA, amoA) and amino acid (AmoA) sequences applying distance-matrix (PHYLIP and FITCH), maximum-parsimony and maximum-likelihood methods using the respective tools in the program package. Since the betaproteobacterial $\mathrm{AOB}$ encompass a closely related group of microorganisms, no conservation filters were applied and all sequence 
Table 1. Pure cultures of $A O B$ used in this study

AOB were obtained from the culture collection of the Institut für Allgemeine Botanik, Abteilung Mikrobiologie, Universität Hamburg, Germany.

\begin{tabular}{|c|c|c|}
\hline Organism & Reference & Origin \\
\hline Nitrosomonas eutropha $\mathrm{Nm} 57^{\mathrm{T}}$ & Koops \& Harms (1985) & Wastewater treatment plant, USA \\
\hline Nitrosomonas sp. Nm59 & S. Sowitzki (unpublished)* & Wastewater treatment plant, Germany \\
\hline Nitrosomonas sp. Nm84 & Stehr et al. (1995a) & Suspended particulate matter, River Elbe, Germany \\
\hline Nitrosomonas sp. Nm148 & H.-P. Koops (unpublished) & Hot spring, Santorin, Greece \\
\hline Nitrosospira sp. Nsp1 & Koops \& Harms (1985) & Soil, Sardinia, Italy \\
\hline Nitrosospira sp. Nsp2 & Koops \& Harms (1985) & Soil, Germany \\
\hline Nitrosospira sp. Nsp5 & Koops \& Harms (1985) & Freshwater cave lake, Sardinia, Italy \\
\hline Nitrosospira briensis $\mathrm{Nsp} 10^{\mathrm{T}}$ & Koops \& Harms (1985) & Soil, Crete \\
\hline Nitrosospira sp. Nsp57 & E. Spieck (unpublished)* & Masonry, Germany \\
\hline Nitrosospira sp. Nsp58 & E. Spieck (unpublished) & Masonry, Germany \\
\hline Nitrosospira sp. Nsp62 & E. Spieck (unpublished) & Masonry, Germany \\
\hline Nitrosospira sp. Nsp65 & E. Spieck (unpublished) & Masonry, Germany \\
\hline Nitrosospira tenuis $\mathrm{Nv1}^{\mathrm{T}}$ & Koops \& Harms (1985) & Soil, Hawaii \\
\hline Nitrosospira sp. Nv6 & Koops \& Harms (1985) & Soil, New Guinea \\
\hline Nitrosospira sp. NL5 & Koops \& Harms (1985) & Wastewater treatment plant, Saudi Arabia \\
\hline Nitrosospira multiformis $\mathrm{NL}^{2} 3^{\mathrm{T}}$ & Koops \& Harms (1985) & Soil, India \\
\hline Nitrosospira sp. L115 & Utåker et al. (1995) & Peat bog, Finland \\
\hline Nitrosospira sp. III7 & Utåker \& Nes (1998) & Spruce forest, Norway \\
\hline Nitrosospira sp. Ka3 & Aakra et al. (1999b) & Soil, Norway \\
\hline
\end{tabular}

${ }^{\star}$ University of Hamburg, Germany.

positions were considered in the calculations. For a more detailed description of the phylogeny inference methods applied, see Purkhold et al. (2000).

\section{RESULTS AND DISCUSSION}

\section{AOB phylogeny inferred from 16S rRNA}

To establish an encompassing high-quality $16 \mathrm{~S}$ rRNA gene database for $\mathrm{AOB}$, we resequenced the respective genes of several $\mathrm{AOB}$ isolates for which only incomplete sequences were available. In detail, $16 \mathrm{~S}$ rRNA gene sequences (nt 1496-1498) were completed for Nitrosomonas spp. Nm58, $\mathrm{Nm} 84$ and Nm86, which represent isolates from the River Elbe (Stehr et al., 1995a). For these strains, only very short 16S rRNA gene sequences (nt 186-281) have been published previously (Stehr et al., 1995a). In addition, ambiguities and errors in the 16S rRNA gene sequences of Nitrosospira spp. Nsp1, Nsp2, Nsp12, Nsp17, Nv6 (all Aakra et al., 2001b), Ka3 (Aakra et al., 1999b), III7 (Utåker \& Nes, 1998) and L115 (Utåker et al., 1995) and Nitrosospira briensis Nsp10
(Aakra et al., 2001b), Nitrosomonas eutropha Nm57 (Aakra et al., 2001b; Head et al., 1993), 'Nitrosovibrio tenuis Nv1' (Head et al., 1993) and Nitrosolobus multiformis Nl13 (Teske et al., 1994) were corrected and the sequences were extended by 23-290 bp to almost full-length (nt 1497-1498).

Furthermore, we determined almost full-length 16S rRNA gene sequences (nt 1494-1501) for the following 12 AOB isolates, which were not characterized at this level previously: Nitrosomonas spp. Nm47, Nm59, Nm143 and Nm148 and Nitrosospira spp. Nsp5, Nsp40, Nsp41, Nsp57, Nsp58, Nsp62, Nsp65 and NL5.

As expected, all 16S rRNA gene sequences determined showed highest similarities (96.7-100\%) to sequences of AOB belonging to the class 'Betaproteobacteria' (available as supplementary data in IJSEM Online). Phylogenetic inference based on 16S rRNA gene sequences of AOB included distancematrix, maximum-parsimony and maximum-likelihood methods and only considered sequences of more than 1000 nucleotides in length. All AOB analysed formed a 
monophyletic group within the class 'Betaproteobacteria'. Within this group, 'Nitrosomonas cryotolerans' forms an independent lineage. In addition, five stable subgroupings (lineages Nitrosomonas oligotropha, Nitrosomonas marina, Nitrosomonas europaea/'Nitrosococcus mobilis', Nitrosomonas communis and Nitrosospira; Stephen et al.,

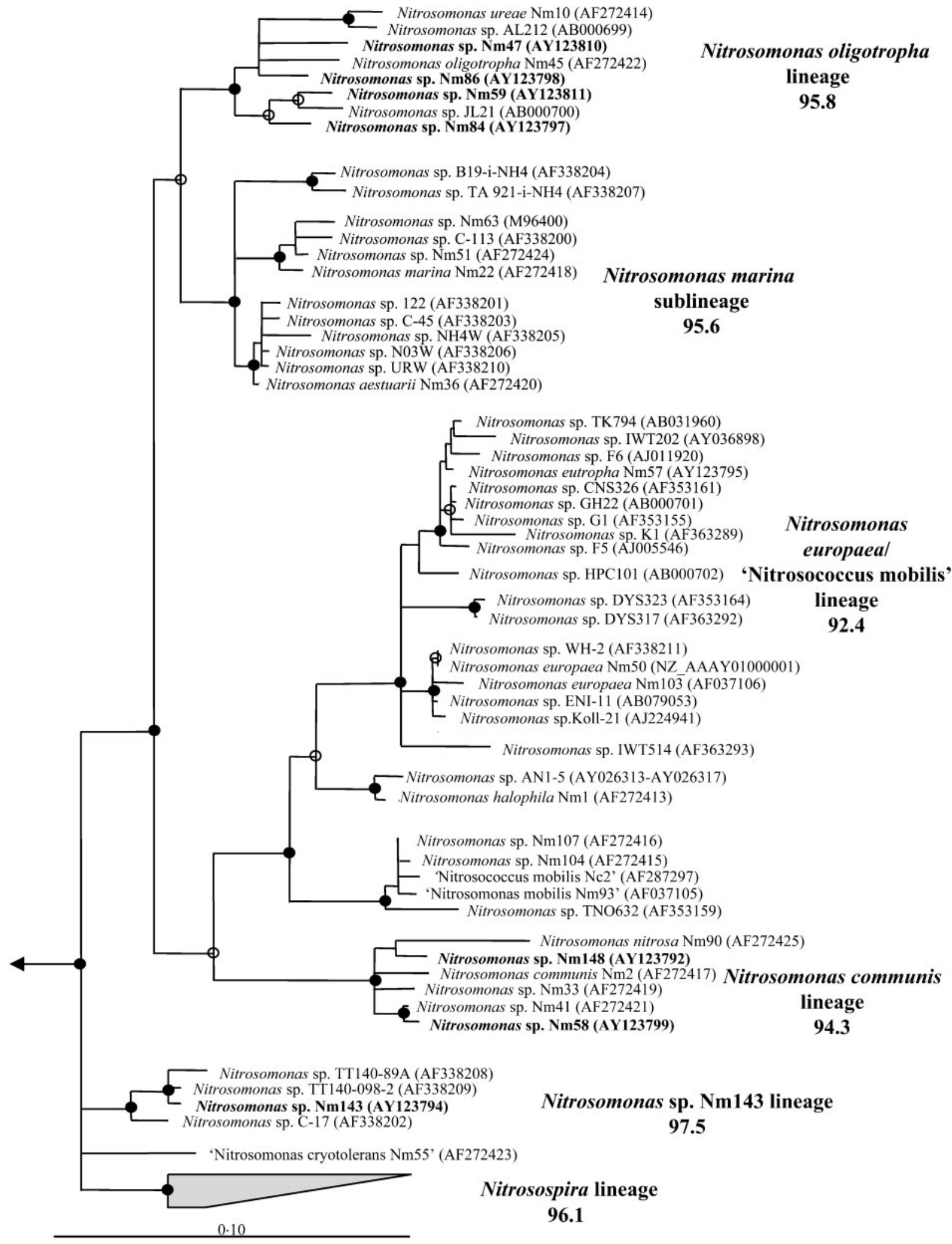


1996; Pommerening-Röser et al., 1996; Purkhold et al., 2000), as well as a lineage not recognized previously (including Nitrosomonas sp. Nm143) were recovered. All groupings are highly supported by parsimony bootstrap analysis (above 90\%) and were found independent from the treeing method applied (Fig. 1). The phylogenetic affiliation of the $12 \mathrm{AOB}$ isolates newly sequenced is summarized below.

\section{Phylogenetic relationship of the newly analysed nitrosomonads. Nitrosomonas isolates Nm47, Nm59, Nm84 and $\mathrm{Nm} 86$ are related most closely to organisms within the Nitrosomonas oligotropha lineage $(97 \cdot 0-97 \cdot 5 \%)$. As have many other members of this group, these isolates have been isolated from either freshwater or wastewater habitats and are characterized by remarkably low affinity constants for ammonia (Koops \& Pommerening-Röser, 2001; Pommerening-Röser et al., 1996; Stehr et al., 1995a; Suwa et al., 1994). Moreover, Nitrosomonas sp. Nm84 has been shown to produce significant amounts of exo- polymeric substances, especially under conditions of limited ammonia (Stehr et al., 1995b); this property has also been observed for other members of this lineage (H.-P. Koops, unpublished results).}

Nitrosomonas spp. Nm58 and Nm148 can both be assigned unambiguously to the Nitrosomonas communis lineage (maximum sequence similarities 99.6 and $98.3 \%$, respectively; Fig. 1). Nitrosomonas sp. Nm148 has been isolated from a hot spring and is a strain of the species Nitrosomonas nitrosa ( $82 \%$ DNA-DNA homology), which has been obtained from activated sludge of a wastewater treatment plant connected to chemical processing facilities (Koops et al., 1991). The 16S rRNA gene sequence of Nitrosomonas sp. Nm58 is almost identical to the sequence of the soil isolate Nitrosomonas sp. $\mathrm{Nm} 41$ (99.6\%). The close relationship between both isolates is also reflected by their high DNA-DNA homology (71 \%). In contrast to the Nitrosomonas oligotropha lineage, the Nitrosomonas communis lineage exhibits a high heterogeneity considering the ecophysiological traits of its members (Koops \& Pommerening-Röser, 2001; Pommerening-Röser et al., 1996).

The only $16 \mathrm{~S}$ rRNA gene sequence obtained in this study that was not related directly to a published sequence from an $\mathrm{AOB}$ isolate was extracted from the estuarine isolate Nitrosomonas sp. Nm143. Considering only described species, the 16S rRNA gene of this organism shows highest sequence similarity to 'Nitrosomonas cryotolerans' (96.7\%). Together with the marine strains C-17, TT140-098-2 and TT140-89A, isolated from sediment samples at the Galapagos Islands and the Washington coast (GenBank accession nos AF338202, AF338209 and AF338208; maximum sequence similarity 99.0 \%; Ward, 1982; Ward \& Carlucci, 1985), Nitrosomonas sp. Nm143 forms a novel lineage within the betaproteobacterial AOB. This lineage is recovered with all treeing methods and is highly supported by bootstrapping. It comprises not only sequences of isolated strains but also harbours 17 16S rRNA gene sequences directly retrieved from different marine habitats (accession nos U09545U09547, Z69090, AJ132050, AJ132056, AY114346, AY114347, AF489686-AF489689, Z69127, Z69134, Z69136, Z69141 and Z69143; de Bie et al., 2001; McCaig et al., 1994; Nicolaisen \& Ramsing, 2002; Stephen et al., 1996; Freitag \& Prosser, 2003). In accordance with the current classification schemes (Pommerening-Röser et al., 1996; Purkhold et al., 2000; Stephen et al., 1996), we propose to designate the new lineage as Nitrosomonas sp. Nm143 lineage. All isolates and sequences within this group originate from a total of eight distinct estuarine or marine habitats. Within these environments, members of the Nitrosomonas sp. Nm143 lineage seem to be distributed widely, since the sampling sites range from coastal surface water (McCaig et al., 1994) to polluted (Stephen et al., 1996) or even anoxic sediments (Freitag \& Prosser, 2003). Nitrogen load and oxygen concentration at the various sampling sites differ significantly [polluted and non-polluted fish farm sediments (Stephen et al., 1996), an eutrophic estuary (Nicolaisen \& Ramsing, 2002) and estuarine sampling sites with ammonium concentrations below $15 \mathrm{mM}$ (de Bie et al., 2001) as well as anoxic sediments (Freitag \& Prosser, 2003) and estuarine sites with oxygen saturation levels around $40 \%$ (de Bie et al., 2001)]. A common feature among the sites investigated are salinity values above 10 p.p.t. Interestingly, however, members of this lineage were not yet detected in the open sea (Bano \& Hollibaugh, 2000; Phillips et al., 1999; Hollibaugh et al., 2002).

\section{Phylogenetic relationship among the newly analysed nitrosospiras. As expected, Nitrosospira isolates NL5, Nsp5, Nsp40, Nsp41, Nsp57, Nsp58, Nsp62 and Nsp65 show the highest $16 \mathrm{~S}$ rRNA gene similarities to sequences within the Nitrosospira lineage (98-6-100\%). Nitrosospira}

Fig. 1. 16S rRNA-based phylogenetic tree of the nitrosomonads. The tree includes all isolates for which $16 \mathrm{~S}$ rRNA gene sequences longer than 1000 nucleotides are available. Species whose sequences have been determined in this study are depicted in bold. Maximum-likelihood, maximum-parsimony and neighbour-joining trees were calculated and merged. Multifurcations connect branches for which a relative order cannot be determined unambiguously by applying different treeing methods. Filled and empty circles indicate parsimony bootstrap values (100 resamplings) above 90 and $70 \%$, respectively. For each lineage, the minimum 16S rRNA sequence similarity between two of its members is depicted. Sequences included in the analysis were published by Aakra et al. (1999a, b), Head et al. (1993), Juretschko et al. (1998), Purkhold et al. (2000), Sorokin et al. (1998), Suwa et al. (1997) and Yamagata et al. (1999). Sequences of strains CNS326, G1, K1, IWT202, TK794, WH-2, Koll-21, DYS317, DYS323, IWT514, TNO632, marine bacteria C-45, NH4W, 122, URW, NO3W, C-113, TT140-098-2, TT140-98A and estuarine bacteria TA 921-i-NH4, B19-i-NH4, C-17 are unpublished but are available at GenBank. Scale bar represents $10 \%$ estimated sequence divergence. 
isolates Nsp57 and Nsp58, which, according to DNADNA hybridization data, are members of the same species (63\% homology; note that AOB strains having more than $60 \%$ DNA-DNA homology are considered as members of the same species; Koops et al., 2003) group together but can be assigned neither to one of the clusters within the cultured nitrosospiras nor to the Nitrosospira cluster 1, which is composed entirely of environmentally retrieved sequences (Stephen et al., 1996). Similarly Nitrosospira sp. Nsp65 forms an independent branch in the Nitrosospira lineage and currently represents the deepest branch within this evolutionary lineage. In contrast, isolate Nsp5 groups with cluster 0 and isolates Nsp 62, Nsp 41, Nsp 40 and NL5 are related most closely to members of the Nitrosospira cluster 3, which contains the three described species of this genus (Fig. 2). Although three of the 12 Nitrosospira-related isolates investigated cannot be assigned to previously suggested clusters of this lineage (Purkhold et al., 2000; Stephen et al., 1996), we refrain from proposing two novel clusters for these АOB because it has been noted that subdivision of nitrosospiras is not well supported by bootstrap analysis (Fig. 2; Purkhold et al., 2000). The failure to recover stable clusters within the nitrosospiras reflects that $16 \mathrm{~S}$ rRNA sequence similarities within the entire Nitrosospira lineage are higher $(>96 \cdot 1 \%)$ than those found within each of the Nitrosomonas lineages described. Furthermore, according to DNA-DNA hybridization data of available strains, Nitrosospira clusters 0 and 2 each currently encompass only strains from a single species. Within cluster 0, Nitrosospira spp. III2, 40KI, Nsp12 and Nsp5 possess DNA-DNA homology values with each other above $67 \%$. Within cluster 2, Nitrosospira spp. III7 and B6 share $76 \%$ DNA-DNA homology. These values indicate that for both groupings of strains, the proposal of additional taxonomic units (clusters 0 and 2) is not justified at this time.

\section{AOB phylogeny inferred from amoA}

During the past few years, the gene encoding the active site subunit of amoA has been exploited increasingly as a marker molecule for AOB diversity research in natural and engineered systems (Baribeau et al., 2000; Gieseke et al., 2001; Horz et al., 2000; Rotthauwe et al., 1997). Initially, amoA gene fragment sequences published previously of Nitrosospira spp. Nsp1, Nsp2, Nsp12, Nsp17, Nv6, Ka3, III7 and L115, Nitrosospira briensis Nsp10 and 'Nitrosovibrio tenuis Nv1' (Aakra et al., 2001a) were extended by 39 bp each to $453 \mathrm{bp}$, which represents the complete fragment obtained after PCR amplification using the modified (Stephen et al., 1999) primer set of Rotthauwe et al. (1997). In addition, $453 \mathrm{bp}$ long amoA sequences were determined for the 12 novel AOB isolates Nitrosomonas spp. Nm47, Nm59, Nm143 and Nm148 and Nitrosospira spp. Nsp5, Nsp40, Nsp41, Nsp57, Nsp58, Nsp62, NL5 and Nsp65. In addition, the $a m o A$ gene fragment sequences of the River Elbe isolates, Nitrosomonas spp. Nm58, Nm84 and Nm86, were determined.
All amoA/AmoA sequences determined showed the highest similarity $(83 \cdot 2-99 \cdot 3$ and $90 \cdot 7-100 \%$, respectively) to sequences of $\mathrm{AOB}$ belonging to the class 'Betaproteobacteria' (available as supplementary data in IJSEM Online). Phylogenetic trees for amoA/AmoA were calculated from the nucleotide and amino acid datasets by distance-matrix, maximum-parsimony and maximum-likelihood methods. In general, topologies of amoA/AmoA- and $16 \mathrm{~S}$ rRNA-based trees were very similar (Figs 1 and 3 ). The monophyly of the Nitrosospira lineage, the Nitrosomonas marina lineage and the Nitrosomonas europaeal'Nitrosococcus mobilis' lineage was recovered by all methods, although the bootstrap support for these lineages was considerably lower than that found for 16S rRNA gene trees. In contrast to $16 \mathrm{~S}$ rRNA trees, the Nitrosomonas oligotropha lineage and the Nitrosomonas communis lineage are not always retrieved in amoA/AmoA trees as monophyletic assemblages (Purkhold et al., 2000).

For all $\mathrm{AOB}$ strains for which the $a m o A / A m o A$ sequence was newly determined in this study, consistent affiliations were found in the $16 \mathrm{~S}$ rRNA gene- and amoA/AmoA-based trees (Figs 1 and 3). However, the amoA/AmoA sequences of the nitrosospiras analysed offer insufficient resolution for inferring details on the phylogenetic substructure of this lineage. The clusters proposed previously within the nitrosospiras are not always monophyletic in amoA/AmoA trees (dependent on the treeing method used) and the bootstrap support of the clusters is very low (data not shown). As expected, the amoA/AmoA sequence of Nitrosomonas sp. $\mathrm{Nm} 143$, the organism representing the novel lineage in the $16 \mathrm{~S}$ rRNA AOB tree, is not closely related to amoA/AmoA sequences of cultured AOB in the database. However, some, but not all, treeing methods suggest a weak affiliation of the amoA/AmoA sequence of Nitrosomonas sp. Nm143 with members of the Nitrosomonas marina and/or Nitrosomonas oligotropha lineages.

With the extending dataset and an increasing number of closely related amoA/AmoA sequences, the limitation of the amoA/AmoA approach as applied now becomes more apparent. Although using the amoA approach, AOB pure cultures or $\mathrm{AOB}$ in environmental samples can be assigned rapidly to some phylogenetic subgroups within this guild (see above), the amoA/AmoA fragment analysed does provide less resolution compared to the 16S rRNA, since it is relatively short (453 nt and 151 aa positions, respectively) and highly conserved (224/93 positions have an identical nucleotide/amino acid in at least $98 \%$ of the betaproteobacterial AOB). This limitation might be solved in future studies by application of primers that allow the amplification of a longer amoA fragment (Norton et al., 2002).

\section{Inconsistencies between determined sequences and published database entries}

To improve the respective databases, we resequenced in this study several $16 \mathrm{~S}$ rRNA and amoA sequences of defined isolates. Comparison of the newly determined sequences 


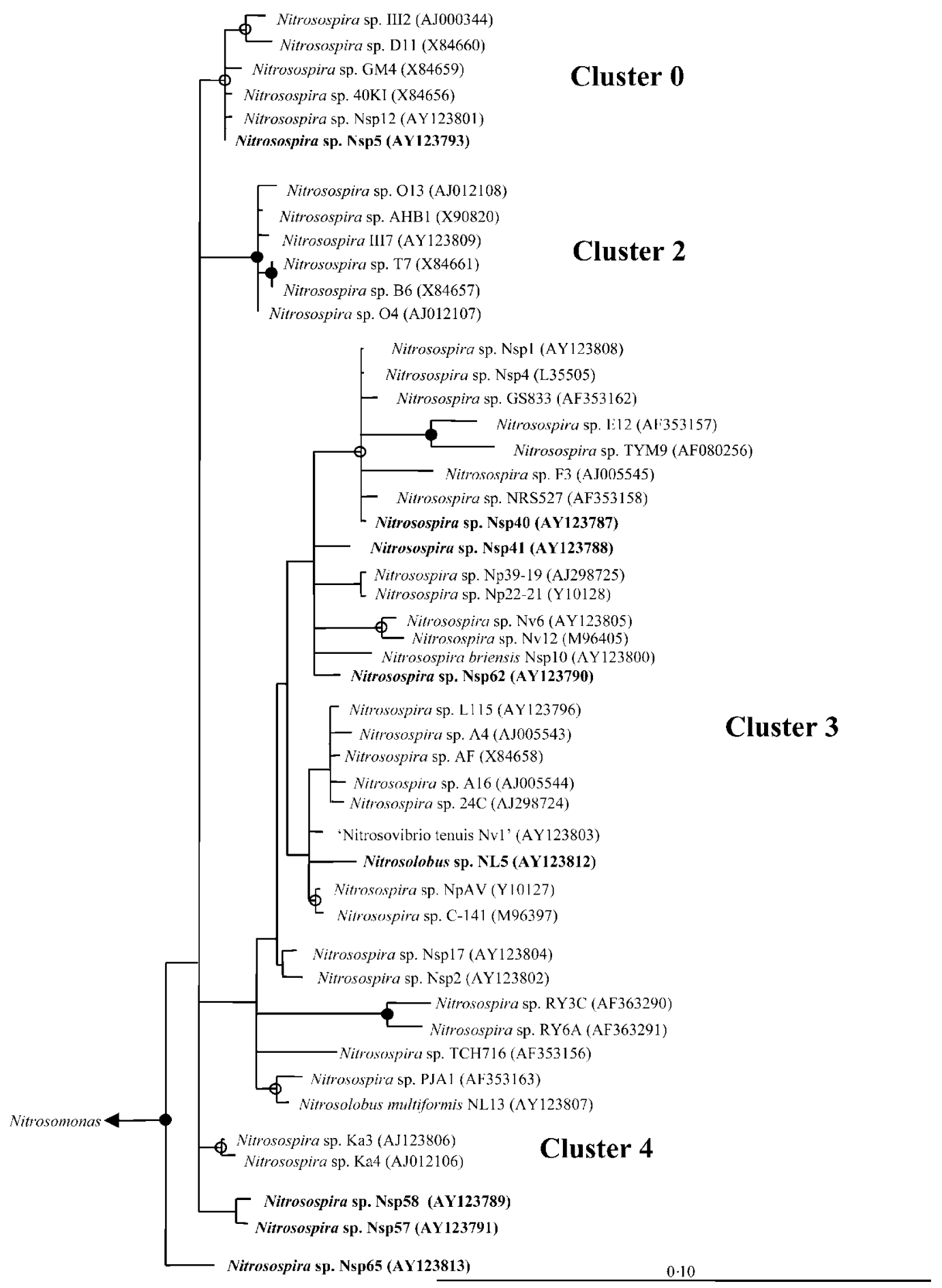

Fig. 2. $16 \mathrm{~S}$ rRNA-based phylogenetic tree of the highly related genera Nitrosospira, Nitrosolobus and 'Nitrosovibrio' forming the Nitrosospira lineage (Head et al., 1993). The tree includes all isolates for which 16S rRNA gene sequences longer than 1000 nucleotides are available. Species whose sequences have been determined in this study are depicted in bold. Maximum-likelihood, maximum-parsimony and neighbour-joining trees were calculated and merged. Multifurcations connect branches for which a relative order cannot be determined unambiguously by applying different treeing methods. Filled and empty circles indicate parsimony bootstrap values (100 resamplings) above 90 and $70 \%$, respectively. Sequences included in the analysis were published by Aakra et al. (1999a, b, 2001b), Head et al. (1993), Teske et al. (1994), Tokuyama et al. (1997) and Utåker et al. (1995). Sequences of strains GS833, E12, NRS527, NpAV, RY6A, RY3C, TCH716 and PJA1 are unpublished but are available at GenBank. Scale bar represents $10 \%$ estimated sequence divergence. 


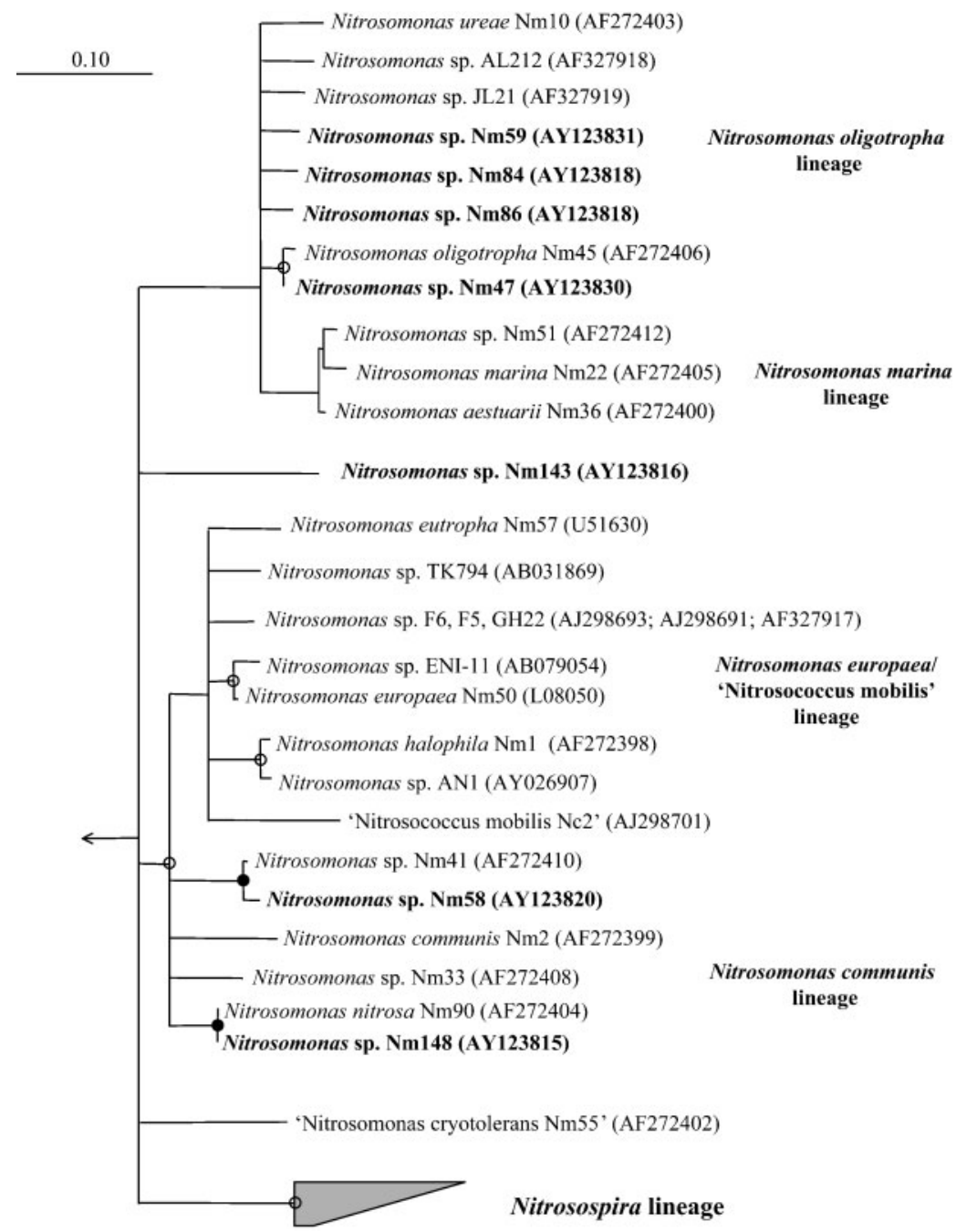

Fig. 3. AmoA-based phylogenetic tree of the betaproteobacterial AOB. Species whose sequences have been determined in this study are depicted in bold. The $453 \mathrm{bp}$ gene fragment obtainable with the amoA PCR primers used most commonly (Rotthauwe et al., 1997) was used for phylogeny inference. AmoA sequences shorter than 414 nucleotides were excluded from the analysis. Protein maximum-likelihood, protein maximum-parsimony, neighbour-joining and FITCH trees were calculated and merged. Multifurcations connect branches for which a relative order cannot be determined unambiguously by applying different treeing methods. Filled and empty circles indicate parsimony bootstrap values (100 resamplings) above 90 and $70 \%$, respectively. Sequences included in the analysis were published by Aakra et al. (2001a), Casciotti \& Ward (2001), Holmes et al. (1995), McTavish et al. (1993), Norton et al. (2002), Purkhold et al. (2000), Rotthauwe et al. (1995), Sorokin et al. (2001), Suwa et al. (1997) and Yamagata et al. (1999). Sequences of Nitrosospira sp. C-57 and Nitrosomonas sp. TK794 are unpublished but are available at GenBank. Scale bar represents $10 \%$ estimated sequence divergence.

with those sequences published previously by others revealed several inconsistencies that could not be explained by simple sequencing errors.

Firstly, differences in the amoA/AmoA sequences (97.6 and $99 \cdot 2 \%$, respectively) of Nitrosospira sp. III7 determined in this study and those published by Aakra et al. (2001a) were detected. However, both sequences show the same phylogeny and, therefore, probably represent two different gene copies. The existence of more than one amoA gene copy is common among betaproteobacterial $\mathrm{AOB}$ and up to four copies have been reported to occur within the genomes of some nitrosospiras (Bock \& Wagner, 2001).

Secondly, we came across published sequences that were obviously retrieved from a contaminant and have not been extracted from the indicated AOB. The $16 \mathrm{~S}$ rRNA gene sequence of 'Nitrosospira sp. Nvl' published by Aakra et al. (2001b) differs significantly (sequence similarity 98.6\%) from the sequences determined in this study (accession no. AY123803) and by Head et al. (1993) (accession no. M96404) and which are almost identical (99.9\%) to each 
other. It seems likely that the latter two sequences are correct also because the close association of Nitrosospira sp. Nv1 with Nitrosospira sp. Nv12 (accession no. M96405, 99.8\%; Head et al., 1993) is not supported by DNA-DNA hybridization data, which demonstrate that the two organisms belong to different species (Pommerening-Röser, 1993). Furthermore, the amoA fragment of Nitrosospira sp. L115 (Aakra et al., 2001a) shows significant sequence differences to the respective sequence determined in this study (nucleic acid, $88.9 \%$; amino acid, $94 \cdot 6 \%$ ). We claim our sequence to be correct since (in contrast to the sequence of Aakra and co-workers) the results of its phylogenetic analysis are in accordance with the respective $16 \mathrm{~S}$ rRNA phylogeny (Fig. 2).

\section{Conclusion}

This study extended significantly the current $16 \mathrm{~S}$ rRNA and amoA databases for $\mathrm{AOB}$. For several $\mathrm{AOB}$ isolates, previously published sequences of both marker molecules were improved in quality and length. Furthermore, gene sequences of both macromolecules were determined for 12 novel AOB isolates. Based on these data, a thorough phylogenetic analysis was performed, which led to the description of a new 16S rRNA gene lineage within the nitrosomonads. This lineage also contains 17 previously unassigned environmental clones, demonstrating that at least one of the new $\mathrm{AOB}$ lineages discovered during the past few years by molecular diversity surveys harbours AOB species that can be cultured by traditional techniques.

\section{ACKNOWLEDGEMENTS}

This study was supported by a grant of the DFG to M. W. (WA1558/1) and a grant from the bmb $+\mathrm{f}$ to M.W. (01 LC 0021 subproject 2, in the framework of the BIOLOG programme). The excellent technical assistance of Sibylle Schadhauser is acknowledged. We kindly thank Thomas Freitag for providing environmentally retrieved 16S rRNA gene sequences prior to publication.

\section{REFERENCES}

Aakra, Å., Utåker, J. B. \& Nes, I. F. (1999a). RFLP of rRNA genes and sequencing of the $16 \mathrm{~S}-23 \mathrm{~S}$ rDNA intergenic spacer region of ammonia-oxidizing bacteria: a phylogenetic approach. Int $J$ Syst Bacteriol 49, 123-130.

Aakra, Å., Utåker, J. B., Nes, I. F. \& Bakken, L. R. (1999b). An evaluated improvement of the extinction dilution method for isolation of ammonia-oxidizing bacteria. J Microbiol Methods 39, 23-31.

Aakra, Å., Utåker, J. B. \& Nes, I. F. (2001a). Comparative phylogeny of the ammonia monooxygenase subunit A and 16S rRNA genes of ammonia-oxidizing bacteria. FEMS Microbiol Lett 205, 237-242; erratum 209, 321.

Aakra, Å., Utåker, J. B., Pommerening-Röser, A., Koops, H.-P. \& Nes, I. F. (2001b). Detailed phylogeny of ammonia-oxidizing bacteria determined by rDNA sequences and DNA homology values. Int J Syst Evol Microbiol 51, 2021-2030.

Bano, N. \& Hollibaugh, J. T. (2000). Diversity and distribution of DNA sequences with affinity to ammonia-oxidizing bacteria of the beta subdivision of the class Proteobacteria in the Arctic Ocean. Appl Environ Microbiol 66, 1960-1969.

Baribeau, H., Kinner, C. A., Stephen, J. R., de Leon, R., Rochelle, P. A. \& Clark, D. L. (2000). Microbial population characterization of suspended and fixed biomass in drinking water. American Water Works Association Water Quality Technology Conference (Salt Lake City, UT, USA, 5-9 November 2000).

Bock, E. \& Sand, W. (1993). The microbiology of masonry biodeterioration. J Appl Bacteriol 74, 503-514.

Bock, E. \& Wagner, M. (2001). Oxidation of inorganic nitrogen compounds as an energy source. In The Prokaryotes: an Evolving Electronic Resource for the Microbiological Community, 3rd edn. Edited by M. Dworkin and others. New York: Springer Verlag. Online http://link.springer-ny.com/link/service/books/10125/.

Casciotti, K. L. \& Ward, B. B. (2001). Dissimilatory nitrite reductase genes from autotrophic ammonia-oxidizing bacteria. Appl Environ Microbiol 67, 2213-2221.

de Bie, M. J. M., Speksnijder, A. G. C. L., Kowalchuk, G. A., Schuurmann, T., Zwart, G., Stephen, J. R., Diekmann, O. E. \& Lånbroek, H. J. (2001). Shifts in the dominant populations of ammonia-oxidizing $\beta$-subclass Proteobacteria along the eutrophic Schelde estuary. Aquat Microb Ecol 23, 225-236.

Frankland, P. F. \& Frankland, G. C. (1890). The nitrifying process and its specific ferment. Philos Trans R Soc Lond B Biol Sci 181, $107-128$.

Freitag, T. E. \& Prosser, J. I. (2003). Community structure of ammonia-oxidizing bacteria within anoxic marine sediments. Appl Environ Microbiol 69, 1359-1371.

Gieseke, A., Purkhold, U., Wagner, M., Amann, R. \& Schramm, A. (2001). Community structure and activity dynamics of nitrifying bacteria in a phosphate-removing biofilm. Appl Environ Microbiol 67, 1351-1362.

Head, I. M., Hiorns, W. D., Embley, T. M., McCarthy, A. J. \& Saunders, J. R. (1993). The phylogeny of autotrophic ammoniaoxidizing bacteria as determined by analysis of $16 \mathrm{~S}$ ribosomal RNA gene sequences. J Gen Microbiol 139, 1147-1153.

Hollibaugh, J. T., Bano, N. \& Ducklow, H. W. (2002). Widespread distribution in polar oceans of a $16 \mathrm{~S}$ rRNA gene sequence with affinity to Nitrosospira-like ammonia-oxidizing bacteria. Appl Environ Microbiol 68, 1478-1484.

Holmes, A. J., Costello, A., Lidstrom, M. E. \& Murrell, J. C. (1995). Evidence that particulate methane monooxygenase and ammonia monooxygenase may be evolutionarily related. FEMS Microbiol Lett 132, 203-208.

Hommes, N. G., Sayavedra-Soto, L. A. \& Arp, D. J. (1998). Mutagenesis and expression of amo, which codes for ammonia monooxygenase in Nitrosomonas europaea. J Bacteriol 180, 3353-3359.

Horz, H. P., Rotthauwe, J. H., Lukow, T. \& Liesack, W. (2000). Identification of major subgroups of ammonia-oxidizing bacteria in environmental samples by T-RFLP analysis of amoA PCR products. J Microbiol Methods 39, 197-204.

Juretschko, S., Timmermann, G., Schmid, M., Schleifer, K. H., Pommerening-Röser, A., Koops, H.-P. \& Wagner, M. (1998). Combined molecular and conventional analyses of nitrifying bacterium diversity in activated sludge: Nitrosococcus mobilis and Nitrospira-like bacteria as dominant populations. Appl Environ Microbiol 64, 3042-3051.

Klotz, M. G. \& Norton, J. M. (1995). Sequence of an ammonia monooxygenase subunit A-encoding gene from Nitrosospira sp. NpAV. Gene 163, 159-160.

Koops, H.-P. \& Harms, H. (1985). Deoxyribonucleic acid homologies among 96 strains of ammonia-oxidizing bacteria. Arch Microbiol 141, 214-218. 
Koops, H.-P. \& Pommerening-Röser, A. (2001). Distribution and ecophysiology of the nitrifying bacteria emphasizing cultured species. FEMS Microbiol Ecol 37, 1-9.

Koops, H.-P., Böttcher, B., Möller, U. C., Pommerening-Röser, A. \& Stehr, G. (1991). Classification of eight new species of ammoniaoxidizing bacteria: Nitrosomonas communis sp. nov., Nitrosomonas ureae sp. nov., Nitrosomonas aestuarii sp. nov., Nitrosomonas marina sp. nov., Nitrosomonas nitrosa sp. nov., Nitrosomonas eutropha sp. nov., Nitrosomonas oligotropha sp. nov. and Nitrosomonas halophila sp. nov. J Gen Microbiol 137, 1689-1699.

Koops, H.-P., Purkhold, U., Pommerening-Röser, A., Timmermann, G. \& Wagner, M. (2003). The lithotrophic ammonia oxidizing bacteria. In The Prokaryotes: an Evolving Electronic Resource for the Microbiological Community, 3rd edn. Edited by M. Dworkin and others. New York: Springer Verlag. Online http://link.springerny.com/link/service/books/10125/.

Kowalchuk, G. A. \& Stephen, J. R. (2001). Ammonia-oxidizing bacteria: a model for molecular microbial ecology. Annu Rev Microbiol 55, 485-529.

MacDonald, R. M. (1986). Nitrification in soil: an introductory history. In Nitrification, pp. 1-16. Edited by J. I. Prosser. Oxford: IRL Press.

McCaig, A. E., Embley, T. M. \& Prosser, J. I. (1994). Molecular analysis of enrichment cultures of marine ammonia oxidisers. FEMS Microbiol Lett 120, 363-367.

McTavish, H., Fuchs, J. A. \& Hooper, A. B. (1993). Sequence of the gene coding for ammonia monooxygenase in Nitrosomonas europaea. J Bacteriol 175, 2436-2444.

Nicolaisen, M. H. \& Ramsing, N. B. (2002). Denaturing gradient gel electrophoresis (DGGE) approaches to study the diversity of ammonia-oxidizing bacteria. J Microbiol Methods 50, 189-203.

Norton, J. M., Alzerreca, J. J., Suwa, Y. \& Klotz, M. G. (2002). Diversity of ammonia monooxygenase operon in autotrophic ammonia-oxidizing bacteria. Arch Microbiol 177, 139-149.

Painter, H. A. (1986). Nitrification in the treatment of sewage and waste waters. In Nitrification, pp. 185-211. Edited by J. I. Prosser. Oxford: IRL Press.

Phillips, C. J., Smith, Z., Embley, T. M. \& Prosser, J. I. (1999). Phylogenetic differences between particle-associated and planktonic ammonia-oxidizing bacteria of the beta subdivision of the class Proteobacteria in the Northwestern Mediterranean Sea. Appl Environ Microbiol 65, 779-786.

Pommerening-Röser, A. (1993). Untersuchungen zur phylogenie ammoniak oxidierender bakterien, p. 50. $\mathrm{PhD}$ thesis, University of Hamburg.

Pommerening-Röser, A., Rath, G. \& Koops, H.-P. (1996). Phylogenetic diversity within the genus Nitrosomonas. Syst Appl Microbiol 19, 344-351.

Purkhold, U., Pommerening-Röser, A., Juretschko, S., Schmid, M. C., Koops, H.-P. \& Wagner, M. (2000). Phylogeny of all recognized species of ammonia oxidizers based on comparative 16S rRNA and amoA sequence analysis: implications for molecular diversity surveys. Appl Environ Microbiol 66, 5368-5382.

Rotthauwe, J. H., de Boer, W. \& Liesack, W. (1995). Comparative analysis of gene sequences encoding ammonia monooxygenase of Nitrosospira sp. AHB1 and Nitrosolobus multiformis C-71. FEMS Microbiol Lett 133, 131-135.

Rotthauwe, J. H., Witzel, K. P. \& Liesack, W. (1997). The ammonia monooxygenase structural gene $a m o A$ as a functional marker: molecular fine-scale analysis of natural ammonia-oxidizing populations. Appl Environ Microbiol 63, 4704-4712.

Sorokin, D. Y., Muyzer, G., Brinkhoff, T., Kuenen, J. G. \& Jetten, M. S. M. (1998). Isolation and characterization of a novel facultatively alkaliphilic Nitrobacter species, N. alkalicus sp. nov. Arch Microbiol 170, 345-352.

Sorokin, D., Tourova, T., Schmid, M. C., Wagner, M., Koops, H.-P., Kuenen, J. G. \& Jetten, M. (2001). Isolation and properties of obligately chemolithoautotrophic and extremely alkali-tolerant ammonia-oxidizing bacteria from Mongolian soda lakes. Arch Microbiol 176, 170-177.

Stehr, G., Böttcher, B., Dittberner, P., Rath, G. \& Koops, H.-P. (1995a). The ammonia-oxidizing nitrifying population of the River Elbe estuary. FEMS Microbiol Ecol 17, 177-186.

Stehr, G., Zörner, S., Böttcher, B. \& Koops, H.-P. (1995b) Exopolymers: an ecological characteristic of a floc-attached, ammonia-oxidizing bacterium. Microb Ecol 30, 115-126.

Stephen, J. R., McCaig, A. E., Smith, Z., Prosser, J. I. \& Embley, T. M. (1996). Molecular diversity of soil and marine 16S rRNA gene sequences related to $\beta$-subgroup ammonia-oxidizing bacteria. Appl Environ Microbiol 62, 4147-4154.

Stephen, J. R., Chang, Y. J., Macnaughton, S. J., Kowalchuk, G. A., Leung, K. T., Flemming, C. A. \& White, D. C. (1999). Effect of toxic metals on indigenous soil beta-subgroup proteobacterium ammonia oxidizer community structure and protection against toxicity by inoculated metal-resistant bacteria. Appl Environ Microbiol 65, 95-101.

Suwa, Y., Imamura, Y., Suzuki, T., Tashiro, T. \& Urushigawa, Y. (1994). Ammonia-oxidizing bacteria with different sensitivities to $\left(\mathrm{NH}_{4}\right)_{2} \mathrm{SO}_{4}$ in activated sludge. Wat Res 28, 1523-1532.

Suwa, Y., Sumino, T. \& Noto, K. (1997). Phylogenetic relationships of activated sludge isolates of ammonia oxidizers with different sensitivities to ammonium sulfate. J Gen Appl Microbiol 43, 373-379.

Teske, A., Alm, E., Regan, J. M., Toze, S., Rittmann, B. E. \& Stahl, D. A. (1994). Evolutionary relationships among ammonia- and nitriteoxidizing bacteria. J Bacteriol 176, 6623-6630.

Tokuyama, T., Yoshida, N., Matasuishi, T., Takahashi, N., Takahashi, T., Kanehira, T. \& Shinohara, M. (1997). A new psychrotrophic ammonia-oxidizing bacterium Nitrosovibrio $\mathrm{sp}$. TYM9. J Ferment Bioeng 83, 377-380.

Utåker, J. B. \& Nes, I. F. (1998). A qualitative evaluation of the published oligonucleotides specific for the 16S rRNA gene sequences of the ammonia-oxidizing bacteria. Syst Appl Microbiol 21, 72-88.

Utåker, J. B., Bakken, L., Jiang, Q. Q. \& Nes, I. F. (1995). Phylogenetic analysis of seven new isolates of ammonia-oxidizing bacteria based on 16S rRNA gene sequences. Syst Appl Microbiol 18, 549-559.

Ward, B. B. (1982). Oceanic distribution of ammonium-oxidizing bacteria determined by immunofluorescent assay. J Mar Res 40, 1155-1172.

Ward, B. B. \& Carlucci, A. F. (1985). Marine ammonia- and nitriteoxidizing bacteria: serological diversity determined by immunofluorescence in sewage plants by flow cytometry. Appl Environ Microbiol 50, 194-201.

Winogradsky, S. (1890). Recherches sur les organismes de la nitrification. Ann Inst Pasteur 4, 213-231 (in French).

Woese, C. R., Weisburg, W. G., Paster, B. J., Hahn, C. M., Tanner, R. S., Krieg, N. R., Koops, H.-P., Harms, H. \& Stackebrandt, E. (1984). The phylogeny of the purple bacteria: the beta subdivision. Syst Appl Microbiol 5, 327-336.

Woese, C. R., Weisburg, W. G., Hahn, C. M., Paster, B. J., Zablen, L. B., Lewis, B. J., Macke, T. J., Ludwig, W. \& Stackebrandt, E. (1985). The phylogeny of the purple bacteria: the gamma subdivision. Syst Appl Microbiol 6, 25-33.

Yamagata, A., Kato, J., Hirota, R., Kuroda, A., Ikeda, T., Takiguchi, N. \& Ohtake, H. (1999). Isolation and characterization of two cryptic plasmids in the ammonia-oxidizing bacterium Nitrosomonas $\mathrm{sp}$. strain ENI-11. J Bacteriol 181, 3375-3381. 